\title{
Bartłomiej Szczepaniak*
}

\section{MARKETING MANAGEMENT IN FMCG INDUSTRY}

\begin{abstract}
A b s t r a c t: The paper is defining the basic notion of FMCG retailers on the Polish market. What is more, the results of the seasonality of sales of different categories of products is depicted. The highest peaks of sales are highlighted. Analysis of sales and data collection from three years period was performed. The virtue products are connected with categories which follows: sex, women epilation, tooth cleaning and air fresheners and moth killers. The conclusions and recommendations concerning promotion and availability of above-mentioned products are shown as well. The article ends with ideas to increase and maximize sales of mentioned categories in the highest season.
\end{abstract}

K e y w o r d s: seasonality, sales, management, FMCG

J E L C o d e: M31

\section{FMCG INDUSTRY}

The fast-moving consumer goods "FMCG" sector states one of the largest industries worldwide. It can be defined as the consumer packaged goods (CPG) sector, it is in majority of cases defined by organizations which supply market with low-cost products that are continuously highly demanded by consumers. Products which are classified as FMCG goods include beverages, food, household cleaning utensils and personal hygiene. The term "fast-moving" relates to the fact that FMCG goods in majority of cases have a short shelf life. From a retailing perspective, FMCG is often cited as a low margin - high volume sales. Companies from FMCG sector mainly focused on products which are less popular but offer higher margin. Within a category, goods often offer almost the same utility, because of that fact price competition between retailers can be

* Adres do korespondencji: Bartłomiej Szczepaniak, Politechnika Łódzka, Wydział Zarządzania i Inżynierii Produkcji, Katedra Zarządzania, ul. Piotrkowska 266, 90-361 Łódź, e-mail: bartekszczepaniak@op.pl 
intense. To increase profitability, companies provide marketing activities and other techniques to switch customers attention into to the product, which enables them to earn more money from margin. Well known FMCG world famous corporations include Procter \& Gamble, Johnson \& Johnson or Rossmann SDP.

Typical characteristics of FMCG products are:

- Individual items with small value however all FMCG goods put together form significant part of the consumer's budget.

- The consumer prefers frequent purchase of goods and keeping optimal, limited inventory of products. In majority of cases these products are perishable.

- People spend little time on the purchase decision. Brand loyalty, recommendations of reliable retailer/dealer and promotions provided by retailers are drivers and accelerators of purchase decisions.

- Trial of a new product i.e. brand switching is often induced by aggressive marketing campaign, recommendation of a friend or a retailer.

- FMCG products refers and satisfy people to necessity, willingness to comforts as well as luxury. They meet the demands of the entire cross section of population. Price and income elasticity of demand varies across products and consumers.

Putting all things to considered, Fast Moving Consumer Gods are all products which people use every day starting from bread, butter and fruits, going into washing powder, perfumes and fabrics softener and finishing with vitamins and antibiotics. This sector is characterized by intense marketing activities which convince final customer to buy the wanted products. This is a result of a market saturation of companies which offer the same products like shampoo. From the point of view of a retailer the biggest profit is provided from the less-known brands. The margin from selling Head and Shoulders shampoo is around 2\% and from shampoo produced by Green Pharmacy or Isana brand is around 12\%. A retailer has to offer the sales drivers like above mentioned $P \& G$ product however the employers are focused to switch customers to the high margin product.

\section{SEASONALITY OF SALES}

Seasonality refers to the fluctuations occur in a monthly or quarterly data series that can be observed at regular intervals. Random variations cannot be treated as seasonality in contrary to fluctuation that occurs more or less at the same interval every year.

Seasonality involves uncontrollable however, at the same time predictable variations in demand over time intervals. The predictability usually is a result of an analysis connected with examination of a recurrent pattern associated with events or activities. The precise pattern can be find and detected and the relevant 
time interval established based on historical sales data. Seasonality period might vary dramatically from industry to industry. Seasonal patterns can be connected with, for instance, peak demand that lasts for days, weeks, months, years. The demand peaks can fit almost any predictable and uncontrollable pattern.

In order to maximize sales and as a result increase profit in the high season intense marketing actions has to be implemented both by suppliers or producers and retailers. During season with the relatively small input the highest profit defined as output can be achieved. Easier is to sell high amount of cream with sun protect factor during summer and winter holidays than in April or December. The significantly more effort and resources have to be encourage to repeat sales from high season during low season. The proportions are so high that companies prefer to introduce another product than to stimulate demand to buy a good during low season period.

\section{NOTION OF MARKETING AND MARKETING MANAGEMENT}

Marketing, by not scientifically connected people is understood as all actions connected with ordering and distribution of leaflets, e-mails to the existing and potential clients and giving gadgets to customers. However, marketing is about more sophisticated actions and values. Marketing is one of the management actions which is present in each organization. Without marketing a company will not be able to sell its product and gain market share. Nowadays numerous of marketing tools enable companies to perform market research, increase its market share or brand awareness.

Definition of marketing other than stated by Kotler is delivered by Peter Shankman - Founder of Help a Reporter Out (HARO) and Social Media Consultant. Author of the book Customer Service - New Rules for a Social Enabled World. He stated that marketing is about creating such an amazing experience around your brand or product, that people with no other connection to it want to tell their friends about how amazing it is, and the cycle begins again.3 This definition refers more to the word of mouth marketing which is focusing on the spreading information about a company via satisfied customers and focusing on the service performance to be on the highest possible level to be remembered by the customer.

The proper marketing management starts with a market analysis during which, five different researches has to be performed what is called the $5 \mathrm{C}$ analysis. The acronym stands for the five areas which have to be examined: customers, company, competitors, collaborations and context. The most important aspect is connected with customers of the company. At the beginning a company has to determine which need will be satisfied by a new product or service. It is crucial for further strategy establishment. For companies from the same type of industry 
the customer type can be different and because of that the marketing strategy will be focused on other aspects.

Next a company's skills have to be evaluated. All strengths and weaknesses have to be taken into consideration and their importance in reaction to the customers' needs fulfillment. The most valuable skills are those which are unique on the market and those which distinguish the organization among others.

Competitors on the market play a significant role on the marketing process as well in-determination whether the situation of the company on the market is perfect - monopolistic position when there is no competition, natural - oligopoly when several competitors are pre-sent on the market and traditional when on the market perfect competition occurs. Concerning the last situation, the company has to put a lot of effort in competitors' analysis to know them as much as possible to have knowledge how to be better than they are. For evaluation of competitors' strategies, strengths, limitations, and future plans importance-performance analysis was designed. During this analysis customers of the specified market industry are asked about importance ranking of key features of the type of product offered by the different producers like quality, price, delivery time, location of shops, after sales service. Having such information, the company can evaluate what is its position on the market and compare it to the situation of competitors and their performance it is crucial when new product will be introduced.

Collaboration is connected with supply chain and human resources evaluation. The company has to ablaze how many people are needed for the whole organization performance and introduction of new product or service. Their qualification is an important aspect as well. After the selection of employees their adequate motivation has to be performed using the hierarchy of motivation factors - the Maslov pyramid. What is more, supply chain and cooperation with suppliers and wholesalers is also crucial for the marketing process of innovation. Level of performance of the all stakeholders engaged in production process has to be at the same level as the final product.

When it comes to the analysis of the external environment of an organization - context stage is performed. Thanks to this analysis the macroeconomic situation can be evaluated and all connected with it factors like cultural, political and legal ones. One of the most common tools for such evaluation is PEST analysis. This tool groups environmental factors which influence on the company into four different sets: political, economic, social and technological ones. Such analysis in visual, clear way depicts the most important factors which influence company performance. It widely used by all types of the organizations worldwide.

Having detailed information about the company's characteristic and macro-economic factors market segmentation process can be introduced which evaluates similarities and differences in clients' needs. Thanks to such analysis some parts, segments of market can be saturated with company's products or services. 
During the process the core aim is to create different customer's profiles based on understanding of their behavior and information about financial status, family size, income and lifestyle. Profiles are related to purchase patterns which fit or not certain products or services. The market segmentation of the service is the mostly visible on the plane where three different classes are offered by airlines. The economy class is designed for tourist and families, business for medium level managers of the companies and upper medium class society member and first class is dedicated to individuals from upper class or top management business people. One air carrier on board using different performance quality can serve three types of customers from different market segments.

Target market analysis is a source of needed information for the organization about identification of people (in B2C marketing) or companies (B2B marketing) which its wants to serve. B2C marketing is focused on the end user of the good and due to that fact, the target market is relatively big. Marketing and branding activities are constantly undertaken because the target group purchasing decisions are made under emotional influence or impact. Having in mind fact that customers, people are the target group of a company the volume of sales is small and the demand for the products or services could be unpredictable. Sometimes people can afford to buy a package of shrimps and in some cases would want to by a salad. Concerning pricing of the products or services, it has to be on the stable level. It would be impossible to negotiate price with all customers because the purchasing decision is made quickly. In addition, for the good instant payment is required.

Abovementioned analysis provides also hints for the management team how to improve customer service of target group. Research process examines following characteristics of the company's clients: demographics (age, occupation, geographic location, gender and in-come), psychographics (opinions, hobbies, activities of customers and culture), good usage (type of occasion, situation and context of use), brand preferences (loyalty of clients to the brand) and decision process (frequency and size of purchase). Organization having those information, verify how previous and current marketing strategies influence on the market and their effectiveness. Results are the basis for creation of a strategy for innovation or improvement of existing products or services. Nowadays bigger attention is put to the psychographics characteristics than to demographics due to the globalization and people diversification. The product or service which is dedicated to the group of people with the same interests or observe similar customs would meet their requirements better than product dedicated to the wider, less specified target group.

Marketing mix which creates the next level in the marketing process is used for defining actions of a company to achieve its objectives in its target market. Marketing mix is also called as $4 \mathrm{P}$ because of four groups of marketing 
tools: product, price, place and promotion. It exemplifies the manner in which companies' marketing strategy is converted into marketing programs for action.

Abovementioned process and its tools can perform targeted and welldesigned marketing campaign which at the end provides profit to a company. The above process is depicted on the graph below.

Pic. 3.1. The marketing process

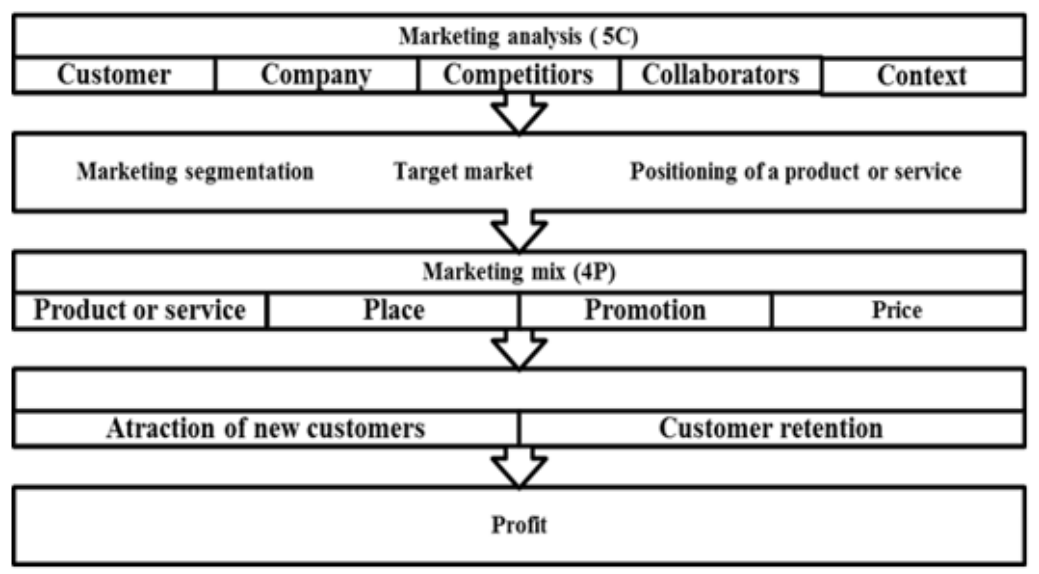

Source: A. J. Silk, Czym jest marketing? Harvard Business Press, Poznań 2008, p.16.

\section{AIM OF THE PROJECT}

The main idea was to collect and analyze data collected from two players on the Polish market and using them define high season of sales of different groups of products. In the result to focus and intensify marketing activities in low popular, not known sales peaks. Thanks to that analysis the biggest profit can be provided to a company and the more people needs can be satisfied. What is more, the supply will answer even more precisely for national, Polish demand.

The data was collected from two biggest players on the Polish market in drug store section. Two of them own almost 50\% market share. The data of sales was collected over three years period - from January 2014 till December 2016. All the quantities had to be add and specific equation was implemented in order not to show the exact data, just to show the tendencies od the demand and to highlight the peaks od sales over the three years period time.

Each of the retailers uses different names for the same groups of products. In order to deliver the highest possible quality of the analysis new groups were created. In each of them the same products are taken into account. In the situation when some products are only offered by one retailers and their utility fit the group they were also added to the analysis. 
What is more, the peaks created by aggressive marketing activities, discounts like $-50 \%$ for make-up products or "buy 2 get 1 for free" are also presented and taken into account for the analysis. It shows how people reacted for a such promotion and for how log their need was satisfied.

In the analysis four different groups were examined:

- Female epilation

- Products for teeth (paste, tooth brush, dental floss and cleaning liquids)

- Sex (condoms, lubricants and accessories)

- Air fresheners + moth killers

\section{ANALYSIS OF SALES}

The first group is connected with female epilation. The activity which is in majority of cases made by female regularly. First idea coming into mind connected with possible peaks of sales is of course before and during vacations when ladies show their body in bikini and swimming suites. The real data are presented in the plot bellow.

Pic. 5.1. Sales of epilation products from 01.01.2014 till 31.12.2016

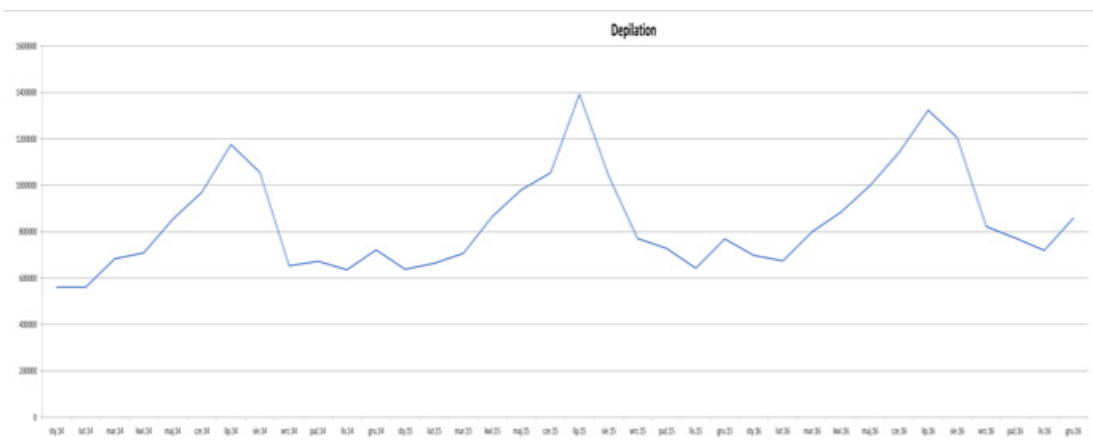

Source: Own elaboration based on own research

As it was mentioned above the highest sales can be observed during the summer months starting from May and ending in September. The aimed additional peaks, intensification of demand and space for marketing actions are observed in Decembers. During this season woman starts preparation for New Year's Eve party. The idea is to look glamorous and fancy. This is also the period when female is wearing dresses and as a result legs are exposed.

The second group is connected with the products which everyone uses at least two times per day everyday - dental products. In this group several products were taken into account: tooth brushes, tooth pastes, dental flosses, and mouth liquids like Listerine. At first it is possible to estimate that the curve of sales should be constant during the year. The actual sales are presented on the chart below. 
Pic. 5. 2. Sales of dental products from 01.01.2014 till 31.12.2016

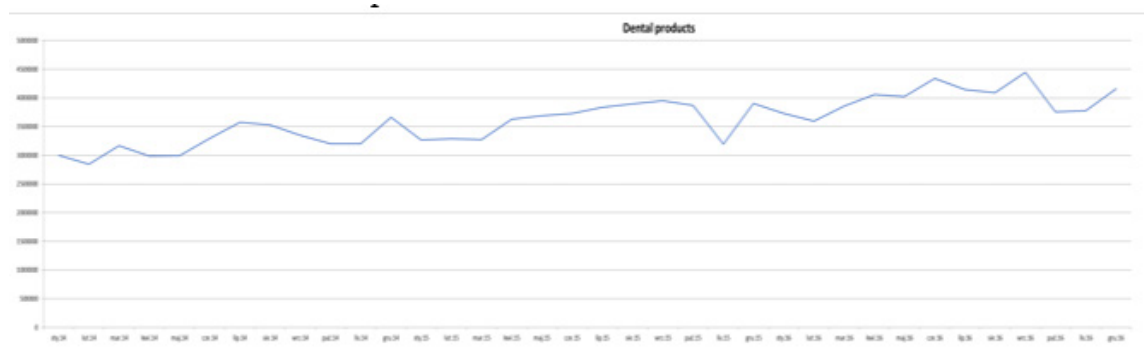

Source: Own elaboration based on own research

What is the most important fact being that the category is growing from year to year. It shows that Polish population constantly is more and more taking care about their tooth. This group is a good example to aim and intensify marketing actions. The small peaks can be detected in December when people want to have Hollywood smile at the end of the year. The detailed research reflected this in numbers that hardly whitening tooth pastes are the most popular in December. When it comes to the summer period which starts from June and ends in September the most popular groups of tooth pastes are those with small volume and those dedicated for children. When it comes to other products of the group their sales over the year is stable. The main marketing actions should be aimed on tooth pastes.

Third group touches the idea of procreation and prevention against venereal disease. It is also connected with the one of the most satisfying and pleasant activity in people life - sex. The products which were taken into account are condoms, lubricants and accessories, gadgets use during abovementioned activity. High season should by in February when Valentine's day is. The real sales are presented on the plot below.

Pic. 5.3. Sales of sex products from 01.01.2014 till 31.12.2016

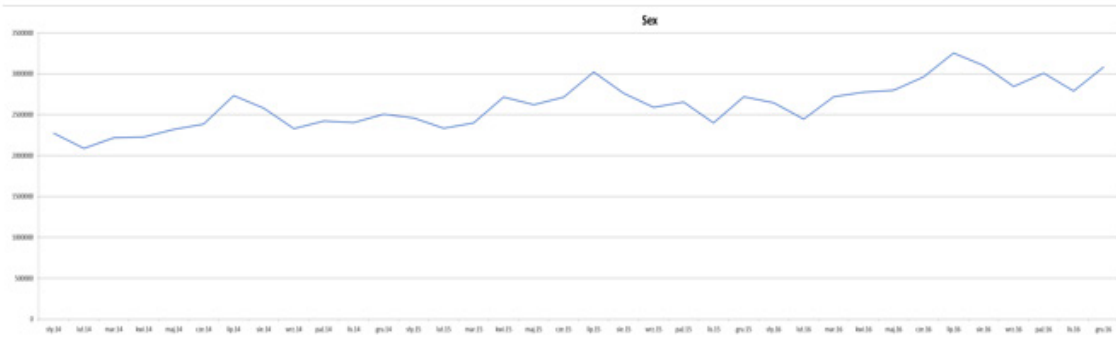

Source: Own elaboration based on own research

Surprisingly, there is no significant peaks of sales in February nor in December. However, there can be observed during the summer period and in contrary to 
other groups not in December but during Easter peaks can be observed. It can be treated as a gate for both retailers and suppliers to promote more intensive mentioned products before Easter holidays. Sales of lubricants is growing by $10 \%$ each year. It shows that people are more open for experiments and are focused for the pleasure maximalization which is showed by $30 \%$ increase of sales year to year in sex gadgets accessories.

The last but not least category which sales is examined are products which change smell in a user house to fragrance and products dedicated for prevention and fighting with moths in user house. The same like for previous cases the estimation of peaks is believed to be at the end of the year when people want to implement the fragrance of Christmas in their houses. Concerning moths summer should be shown as a peak when winter clothes are full of moths after the winter season. The actual, real data is shown on the chart below.

Pic. 5.4. Sales of air fresheners and moth killer's products from 01.01.2014 till 31.12.2016

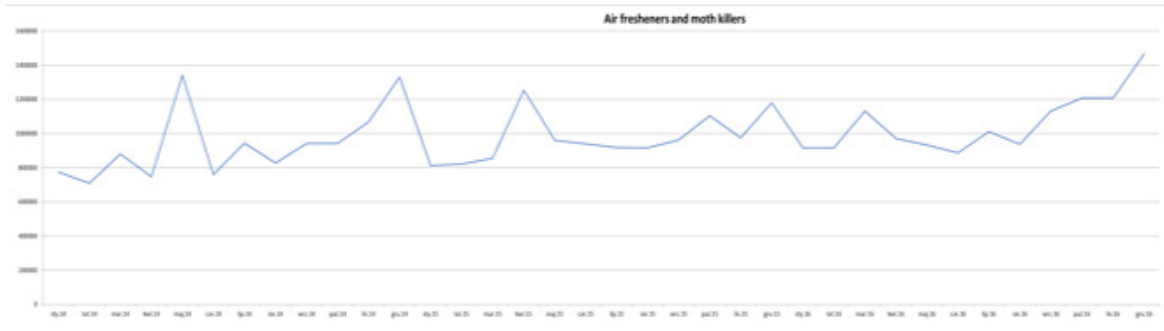

Source: Own elaboration based on own research

The analysis showed that the two types of products represent complementary seasonality during the year. When the one noted peak the second one not and vice versa. Going more deeply into the plot, peaks of sales concerning air fresheners can be observed in November and December as it was mentioned above. Easter period is reserved for moth killers when people started do clean their houses and discovered moths in their wardrobes. What is also worth to highlight is fact that amplitude, difference between peaks and standard sales is lower over years. It was the only group when the seasonality peaks can be forecasted and marketing actions were implemented properly and as a result sale was increased over the whole year.

\section{RECOMMENDATIONS FOR THE FUTURE}

The main aim of a retailer is to stimulate customers to purchase more and more frequently. On the saturated market organizations have to think out of the box and be customer oriented. Based on the analysis presented above and space to conduct more detailed researches based on the information obtained from the Customer Relation Management system - mobile applications provided by the 
retailers for its clients - and data from cash desks about groups of purchased products, retailers can provide better aimed and tailor-made promotions for their customers. Nowadays, retailers encourage people to buy more by organizing promotions for make-up goods, cleaning or children care products. They are for everyone and its aim is to increase total value of the receipt by increasing person stock with products from the same category. Customer without child will not take advantage of a such promotion. The same situation is with male customers who will not buy make-up products.

The virtute trend in all organization is to provide tailored made product or service which will satisfy its owner or user at the highest possible way. Both mentioned companies have enough information and data to provide personal offer for its clients. For example, for a male who do like sport and has a dog mainly products from those categories should be offered. At the same time, additional complementary and seasonal products should be added to the personal offer.

Implementation of above strategy will provide a company with loyal customers and at the same time step by step can influence on their decisions and can provide product switch as an additional service for a producer. For instance, in case of shampoo from one company, this from competitor can be promoted and posted on customer accounts.

Only cost of the investment from the retailer side is to provide high quality analysis and create a code or algorithm which will analyze people purchase behavior and will and to their preferences complementary products.

\section{CONCLUSIONS}

In the paper basic notions of FMCG industry and seasonality was delivered. After that aim of the research was presented. Data was collected from two biggest corporations, retailers in drug store section. The range of data was three years. The plot and unexpected peaks of sales in four different categories of products. Each of them is seasonal several times during the year. The most important are niche peaks where space for marketing activities is observed, market is not yet saturated.

Epilation products dedicated for female have two seasons one more obvious during summer period and the second one during the end of the year, before New Year's Eve when promotion can be introduced. One of the ideas is to combine this season with dental products especially whitening tooth paste just before end of a year. This group has the biggest sales during summer and as well as in December. However, type of product differs in those peaks.

When it comes to the condoms, lubricants and sex gadgets sales does not reflect the reality. The biggest sale is noticed in Easter period- in March and April - not like people normally think that in February when Valentines are. The pro- 
motional actions should be implemented especially in this period. What is more, well prepared and well targeted marketing campaigns for lubricants and gadgets are recommended to be introduced. The demand for those products is constantly and rapidly growing. It can be defined as stars concerning BCM matrix.

All in all, the research showed that even in saturated market like drug stores and FMCG products there is a space to increase and stimulate demand to purchase more. It can be defined as reactive actions What is the most important fact, it is not an artificial creation of human need, it is increase of already existed need and take advantage of the people initial input - purchase.

When it comes to the recommendation, the main idea is to focus on the data which retailers already have. The next step is analysis and release of the tailor-made offer for their customers. Application of those two activities will provide several benefits for all stakeholders. Customers will obtain perfect fitted offer, retailers can reach all target markets and satisfy more needs, what is more, gain loyal customers. Suppliers and producers can increase theirs market share and influence on the demand on their products and increase it by switching process. The most important and powerful tool is knowledge and its proper usage.

\section{REFERENCES}

Cardinal P, Camille L, (2014), The Importance of Taking Seasonal Patterns into Account in the Analysis of Real Estate Market Statistics, Market Analysis Department of the QFREB, Quebec.

Carvalho de Mesquita J. M. , Martins H. C, (2011), Retail industry: seasonality in sales, and financial results, Brazilian Business Review, Vitoria.

Krider, Robert E. and Charles B. Weinberg (1998), Competitive Dynamics and the Introduction of New Products: The Motion Picture Timing Game, Journal of Marketing Research 35 (February)

Radas, Sonja and Steven M. Shugan, (1998), "Managing Service Demand: Shifting and Bundling," Journal of Services Research, Vol. 1, No. 1, (August).

Shankman P., Customer Service: New Rules for a Social Media World, Que Biz-Tech, USA 2010, p. 120.

Szczepaniak B, (2017), “Curbing falling sales through innovation” Lodz Univeristy of Technology, Lodz.

\section{MARKETINGOWE ZARZĄDZANIE W SEKTORZE FMCG}

Zarys treści: Artykuł definiuje podstawowe kwestie związane z sektorem FMCG na rynku polskim. Ponadto przedstawiono wyniki sezonowości sprzedaży różnych kategorii produktowych. Najwyższe szczyty sprzedaży zostały wyróżnione. Przeprowadzono analizę sprzedaży na podstawie danych z okresu trzech lat. Analizowane produkty należą do następujących kategorii: seks, produkty do depilacji dla kobiet, produkty higieny jamy ustnej, odświeżacze powietrza oraz środki owadobójcze. Przedstawiono także wnioski i zalecenia dotyczące promocji i dostępności wyżej wymienionych produktów. Artykuł kończy się pomysłem na zwiększenie i maksymalizację sprzedaży wspomnianych kategorii w najwyższym sezonie.

Słowa kluczowe: sezonowość, sprzedaż, zarządzanie, FMCG 
